\title{
Petrographic evidence for hydrocarbon migration in Lower Cambrian sandstones, Bornholm, Denmark
}

\author{
LARS NICOLAI NEBEL MØLLER \& HENRIK FRIIS
}

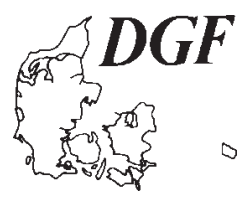

\begin{abstract}
Møller, L. N. \& Friis, H.: Petrographic evidence for hydrocarbon migration in Lower Cambrian sandstones, Bornholm, Denmark. Bulletin of the Geological Society of Denmark, Vol. 45, pp. 117-127. Copenhagen, 1999-01-30. https://doi.org/10.37570/bgsd-1998-45-11
\end{abstract}

The Lower Cambrian sandstones from Bornholm, and in particular the Hardeberga Sandstone, contain a substance that has been interpreted to be pyrobitumen which causes the dark colour seen at many outcrop localities. The presence of pyrobitumen indicates the former presence of hydrocarbons that migrated through the sandstones during the Mid Palaeozoic subsidence. In contrast to previous assumptions it is shown that even though the sandstones were extensively compacted, it had only very little cement, and consequently excellent reservoir qualities at the time of hydrocarbon generation and migration. The only known source rock is the Middle Cambrian Alum Shale that must have been down-faulted relative to the lower Cambrian sandstones at the time of hydrocarbon generation. Quartz cement did not form until deep burial, and similar sandstones at locations outside the onshore Bornholm area that have not been so deeply buried may not have quartz cement and therefore still posses good reservoir properties.

Key words: Hardeberga Sandstone, Nexø Sandstone, pyrobitumen, Lower Cambrian, Bornholm, hydrocarbon migration, compaction, quartz cementation, reservoir properties.

Lars Nicolai Nebel Mфller \& Henrik Friis, Department of Earth Sciences, University of Aarhus, C. F.Mфllers Allé 120, 8000 Århus C, Denmark. April 17, 1998.

The Hardeberga Sandstone (Balka Sandstone) is known as a white to pale grey sandstone, but in many localities on Bornholm the colour is much darker grey or black. Similarly, the Nexø Sandstone known as a red sandstone is locally anomalously dark. Sandstones with a mineralogical composition similar to Hardeberga Sandstone and Nexø Sandstone are normally considered to be white and reddish respectively; consequently there must be an anomalous component that is locally dying the sandstone.

There has been much speculation concerning the origin of the dark colour, but due to lack of evidence most workers have indicated unspecified organic matter as most probable. This "organic matter" is viewed as a syndepositional component of the sediment, and not material that entered the sediment after deposition. However, coarse-grained sediments like the Nex $\varnothing$ Sandstone, Hardeberga Sandstone, and Rispebjerg Sandstone, deposited in fluvial or shallow marine environments do not normally contain finely disseminated organic matter.
This paper ascribes the dark colour of these sandstones to a content of pyrobitumen, a residue after fluid hydrocarbons that migrated through the rocks during mid Palaeozoic burial. Furthermore, it is shown that the reservoir quality of the sandstones was good when hydrocarbons were generated.

The work is mainly based on the Hardeberga Sandstone because of the number of samples available, and because compaction studies are particularly applicable to this sandstone. However, many of the observations described have also been made in the other Lower Cambrian sandstones: Nexø Sandstone, and Rispebjerg Sandstone. The Broens Odde Member (Green Shales) that lies stratigraphically between the Hardeberga Sandstone and Rispebjerg Sandstone (Fig. 1) was not included in the study.

The Lower Cambrian Nexø Sandstone was deposited in a fluvial and eolian environment (Clemmensen \& Dam 1993) and is the oldest sedimentary unit in Bornholm (Fig. 1). Mineralogically it is of arkosic to subarkosic composition (feldspar rich) (sandstone 


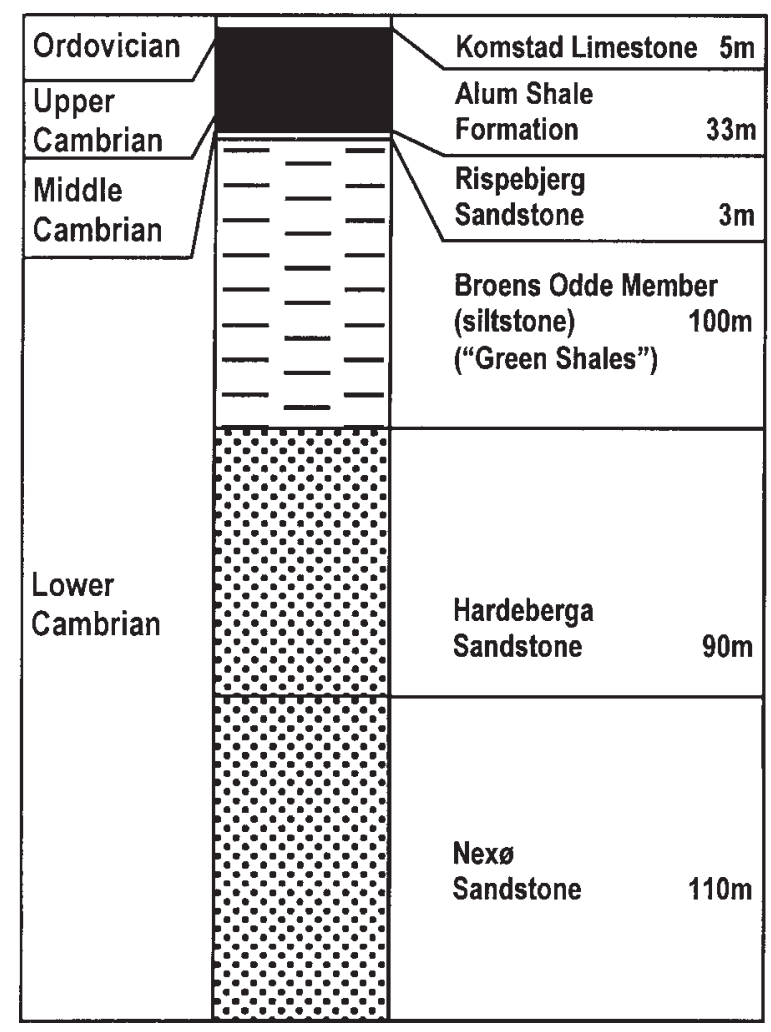

Figure 1. Stratigraphic sequence. Individual units are shown with comparable thicknesses excluding hiatuses. Thicknesses are maximum thicknesses recorded in the literature.

classification: Folk 1980) and is mostly reddish in colour from a content of feldspar and hematite. The overlying Hardeberga Sandstone, interpreted as shallow marine (Hamberg 1991), is mainly of quartzarenite composition (quartz rich) and is mostly light grey in colour. The Rispebjerg Sandstone also interpreted as shallow marine (Grönwall \& Milters 1916, Hansen 1937) is mineralogically similar to the Hardeberga Sandstone and therefore also classified as a quartzarenite. All the sandstones mentioned are highly compacted and thoroughly cemented by quartz, and consequently have very little porosity at present.

\section{Previous work}

Hansen (1936) observed that the dark coloured sandstone was bleached when heated to high temperatures which he suggested was due to the burning of the organic matter, but did not identify the type of material.

Dark arkoses with a composition similar to the Nex $\varnothing$ Sandstone are particularly common south and southeast of Aakirkeby, whereas dark quartzarenitic Hardeberga Sandstone is present at most localities throughout the outcrop area in southern Bornholm. Hansen
(1936) considered both dark Hardeberga Sandstone and Nexø Sandstone as distinct lithologies, which led him to suggest the name "Aaker Formation" for dark blue-grey arkoses in the vicinity of Aakirkeby. This was later rejected by Gry (1936) for stratigraphic reasons, and it is probably more correct to consider this unit as part of the Nexø Sandstone Formation.

Jensenius (1987) identified isolated liquid hydrocarbon inclusions in the Ordovician calcareous rocks overlying the Alum Shale. These inclusions suggest that the Alum Shale generated oil in the Palaeozoic. Jensenius (1987) also reported a possible occurrence of small quantities of gas hydrate in the fluid inclusions found in a quartz vein in Hardeberga Sandstone. However, because the Hardeberga Sandstone has very little porosity at present, it has been assumed that it was already cemented when oil was generated, or that the oil was prevented from entering the sandstone for stratigraphical reasons (Buchardt et al. 1997).

\section{Methods of study}

Samples were collected from many surface localities in Bornholm, the most important of which were: Strøby Quarry south of Aakirkeby, Pedersker Quarry north of Pedersker, and Godthaab and Tvillinghuse

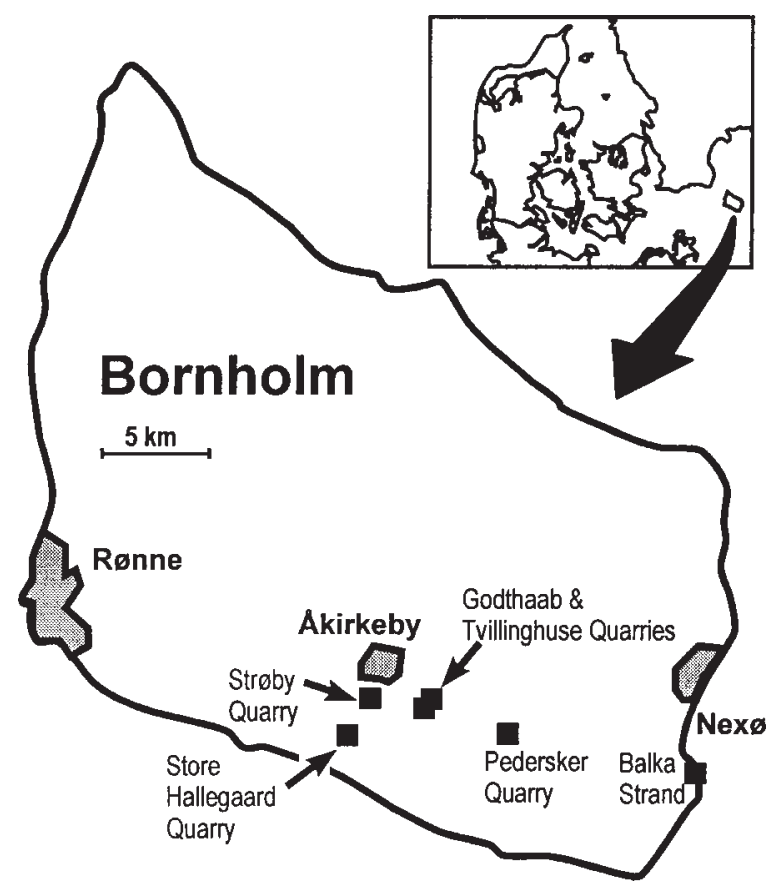

Figure 2. Map showing the geographical location of Bornholm, and the most important outcrop localities with sandstones containing pyrobitumen. Black Hardeberga Sandstone is found throughout the outcrop area, whereas dark Nexø Sandstone is most common southeast of Aakirkeby. 
Quarries southeast of Aakirkeby (Fig. 2). For a detailed map of localities see Hansen (1936).

The most important method of study was thin section microscopy. A number of thin sections were pointcounted, counting 500 randomly chosen points on each thin section, to enable the quantification of the detrital volume and intergranular volume (IGV).

Pointcounts using a petrographic microscope were undertaken when surfaces of detrital grains could be distinguished from quartz overgrowths by visible dustrims. In many samples, however, there are no visible dustrims, and scanned cathodoluminescens microscopy (CL) was applied to create a better contrast between detrital quartz grains and quartz cement. In most cases, authigenic quartz luminesced significantly less than detrital quartz, and therefore the detrital grains were easily distinguished from cement. Furthermore, the difference in contrast between detrital and authigenic phases enhance fine fractures filled with cement.

\section{Burial history}

The average sedimentation rate during most of the Lower Palaeozoic was extremely low, and rapid burial did not commence until the Late Silurian in association with the Caledonian deformation. Exactly how rapid and how deep the sandstones were buried is not known, but stable isotope studies indicate burial in excess of $2000 \mathrm{~m}$ (Buchardt \& Nielsen 1985). Basin analysis studies suggest that burial must have been in the order of $4000 \mathrm{~m}$ (Fig. 3), and that uplift was during the Late Carboniferous (Jensen \& Nielsen 1995, Vejbæk et. al. 1994). Furthermore, vitrinite-like macerals in the Alum Shale show reflectance values up to $2.5 \%$ (Thomsen et al. 1983, Buchardt \& Lewan 1990), indicating deep burial and over-maturation with respect to hydrocarbon generation. Generation of hydrocarbons from the Alum Shale most probably hap-

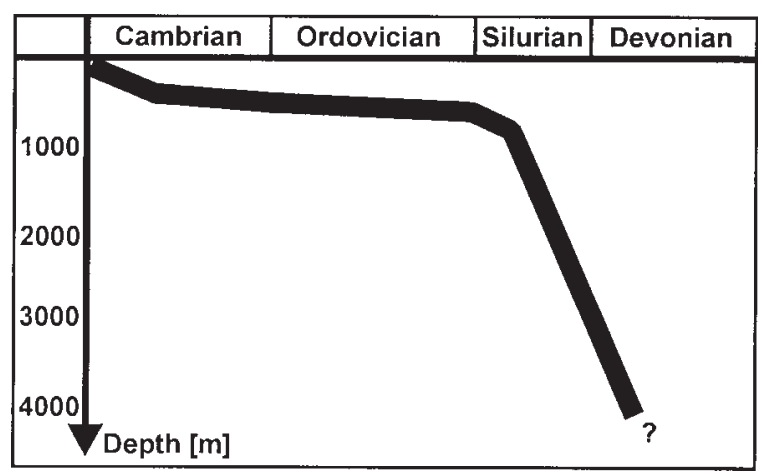

Figure 3. Burial curve showing that subsidence was slow through most of the Early Palaeozoic. Subsidence rate did not increase until Late Silurian in association with the Caledonian orogeny. Based on Vejbæk et al. (1994).

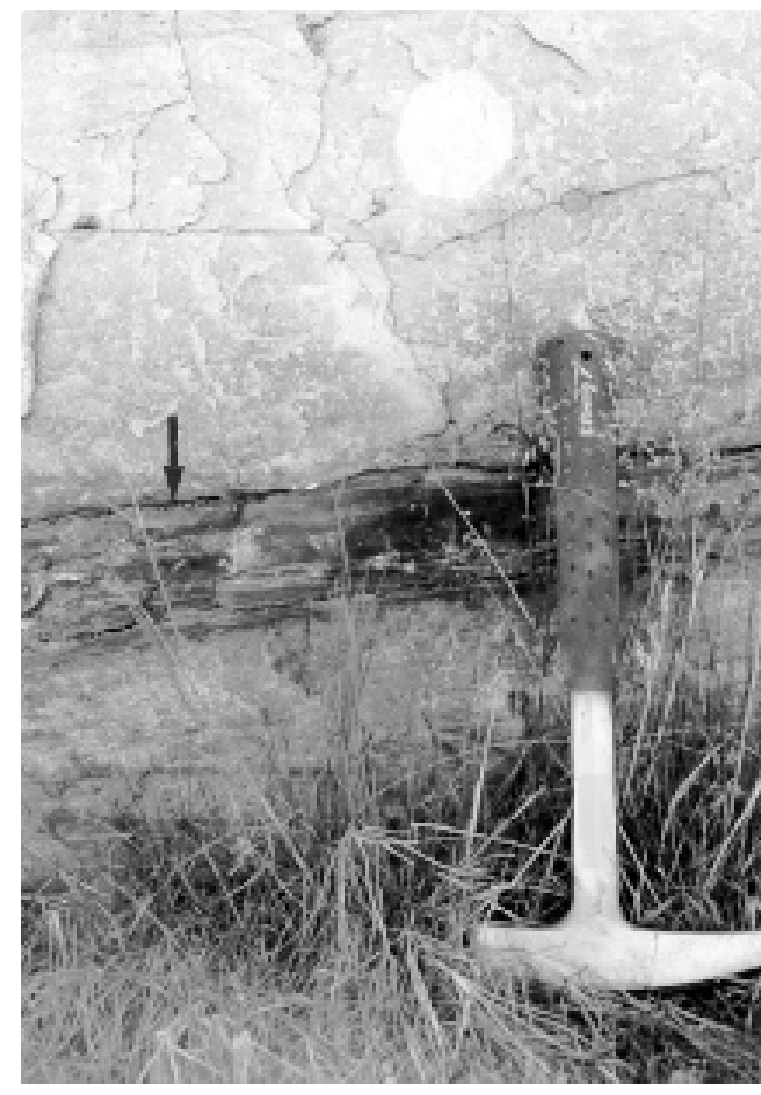

Figure 4. Dark uncemented layer (below arrow) in Hardeberga Sandstone, Strøby Quarry south of Aakirkeby. The dark colour decreases with distance from the layer. Hammer for scale. (The circular area in the upper part of the image is a reflection spot in the camera)

pened during the Late Silurian to Early Devonian burial (Buchardt et al. 1997), which also caused the main diagenetic event including compaction and cementation of the sandstones studied here.

\section{Field observations}

Dark coloured Hardeberga Sandstone can be seen at most outcrop localities, but constitutes less than $10 \%$ of the total sandstone volume. The best locality is the abandoned sandstone quarries at Pedersker, but dark Hardeberga Sandstone was also sampled from the Læså streambed, Store Hallegård Quarry, Strøby Quarry, and Balka Strand.

In the north wall of the Pedersker Sandstone Quarry, the grey massive sandstone contains dark irregular patches, on a centimetre to decimetre scale, and larger dark coloured areas. The dark areas are oriented parallel to bedding and can be traced for many metres laterally. They also show some tendency to follow large-scale cross bedding, but because they crosscut 


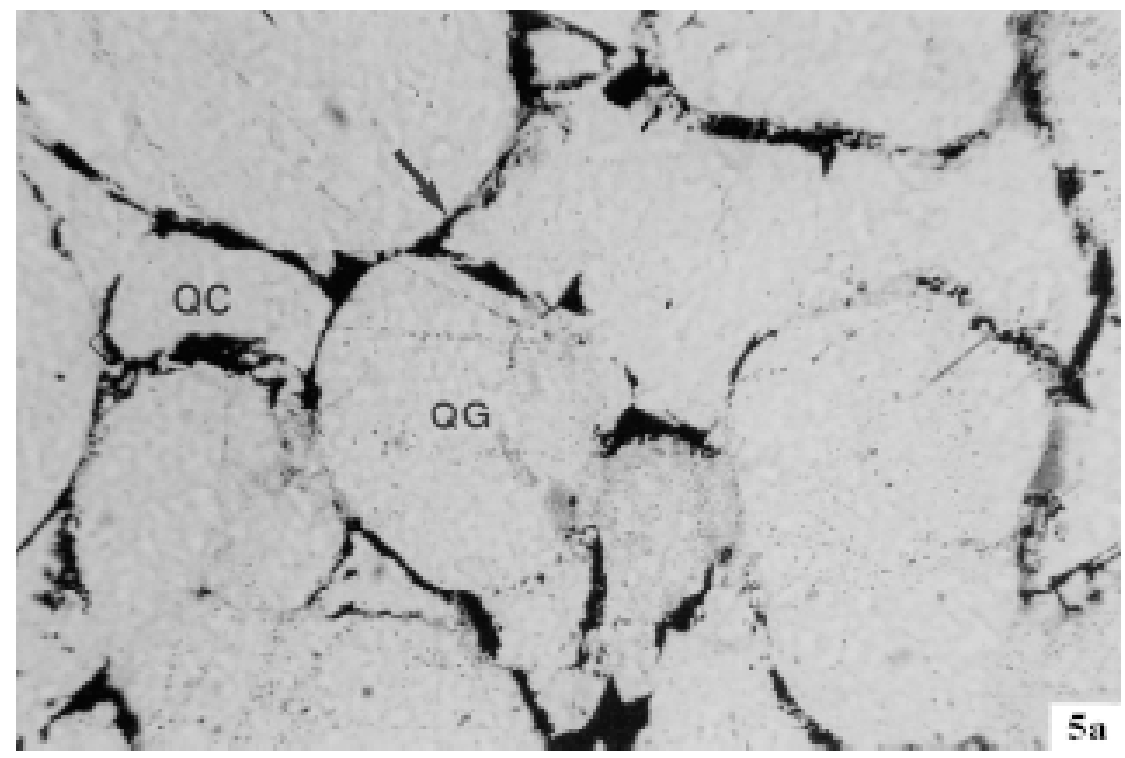

Figure 5. Pyrobitumen coating on surfaces of grains a) Hardeberga Sandstone from Tvillinghuse with thin pyrobitumen coating directly on the surface of detrital grains (arrow). No clay. QG = quartz grain. $\mathrm{QC}=$ quartz cement. Plain light. Full width of image is $1.0 \mathrm{~mm}$. b) Same as 6a but at higher magnification. $\mathrm{PB}=$ pyrobitumen. $\mathrm{Q}=$ quartz. Plain light. Full width of image is $0.16 \mathrm{~mm}$.

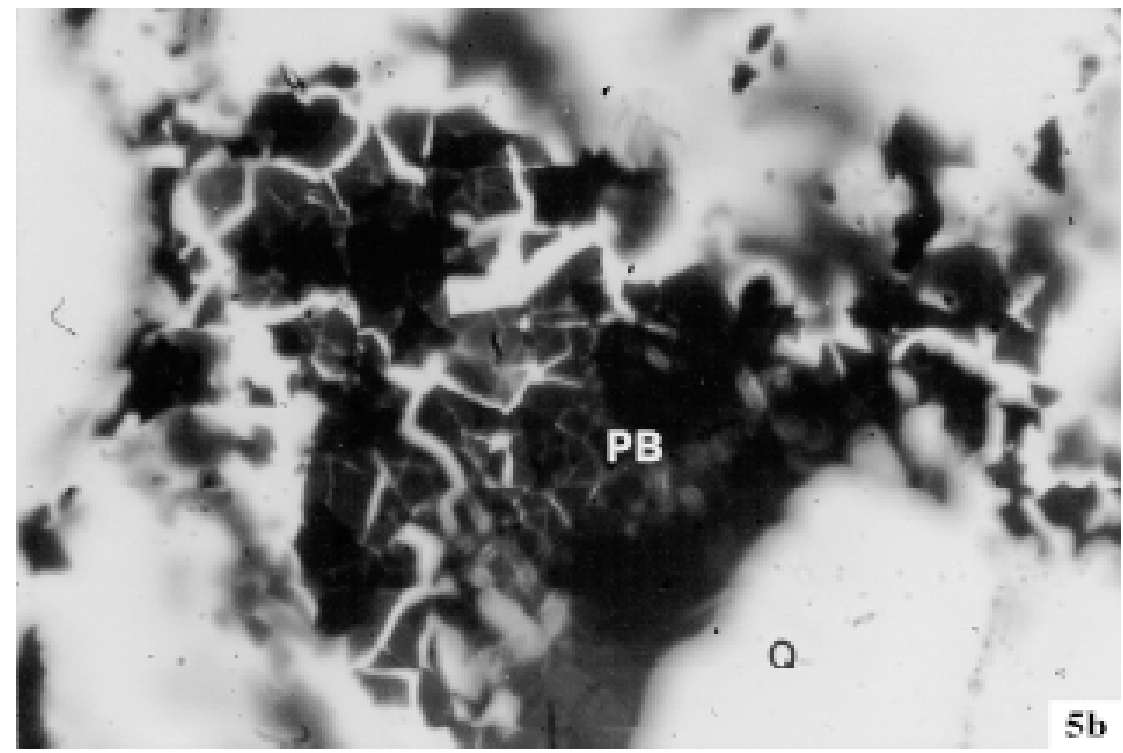

individual cross-bedding surfaces they can not be of syndepositional origin.

The dark colour is also seen to be associated with the upper and lower margins of intercalated uncemented fine-grained layers, with the dark colour decreasing in intensity with distance from the layer (Fig. 4). In the south west corner of Pedersker Sandstone Quarry, a few square metres of a completely dark bedding surface of the Hardeberga Sandstone is exposed, and here too the degree of colouring decreases with distance from the bedding surface.

Most dark coloured Nexø Sandstone is found at localities within five kilometres south east of Aakirkeby (Hansen 1936), but it is also found in small amounts in the beach exposure at Balka Strand, just north of
Balka Harbour. The best exposure is in the old sandstone quarry close to the "Godthaab" farm. Here the same patterns as described above for the Hardeberga Sandstone in Pedersker Quarry, can be seen in both fine-grained to medium-grained and coarse-grained conglomeratic lithologies, all of arkosic to subarkosic composition. The Godthaab exposure is close to the stratigraphical boundary between Nexø Sandstone and Hardeberga Sandstone and from Hansen's map it is hard to conclude whether this unit is Nexø Sandstone or Hardeberga Sandstone. However, the high content of feldspar suggests that this is actually Nexø Sandstone, although it does not have the characteristic red colour. 
Figure 6. Pyrobitumen in microporous intergranular clay. a) Hardeberga Sandstone (quartzarenite) from St. Hallegaard Quarry with pyrobitumen and clay in intergranular porespace (dark substance). All other porespace (IGV) is filled with quartz cement. Plain light. Full width of image is $1.0 \mathrm{~mm}$. b) Arkosic sandstone (Nexø Sandstone) from Godthaab Quarry with pyrobitumen and clay in intergranular porespace (dark substance). Plain light Full width of image is 0.63 $\mathrm{mm}$.
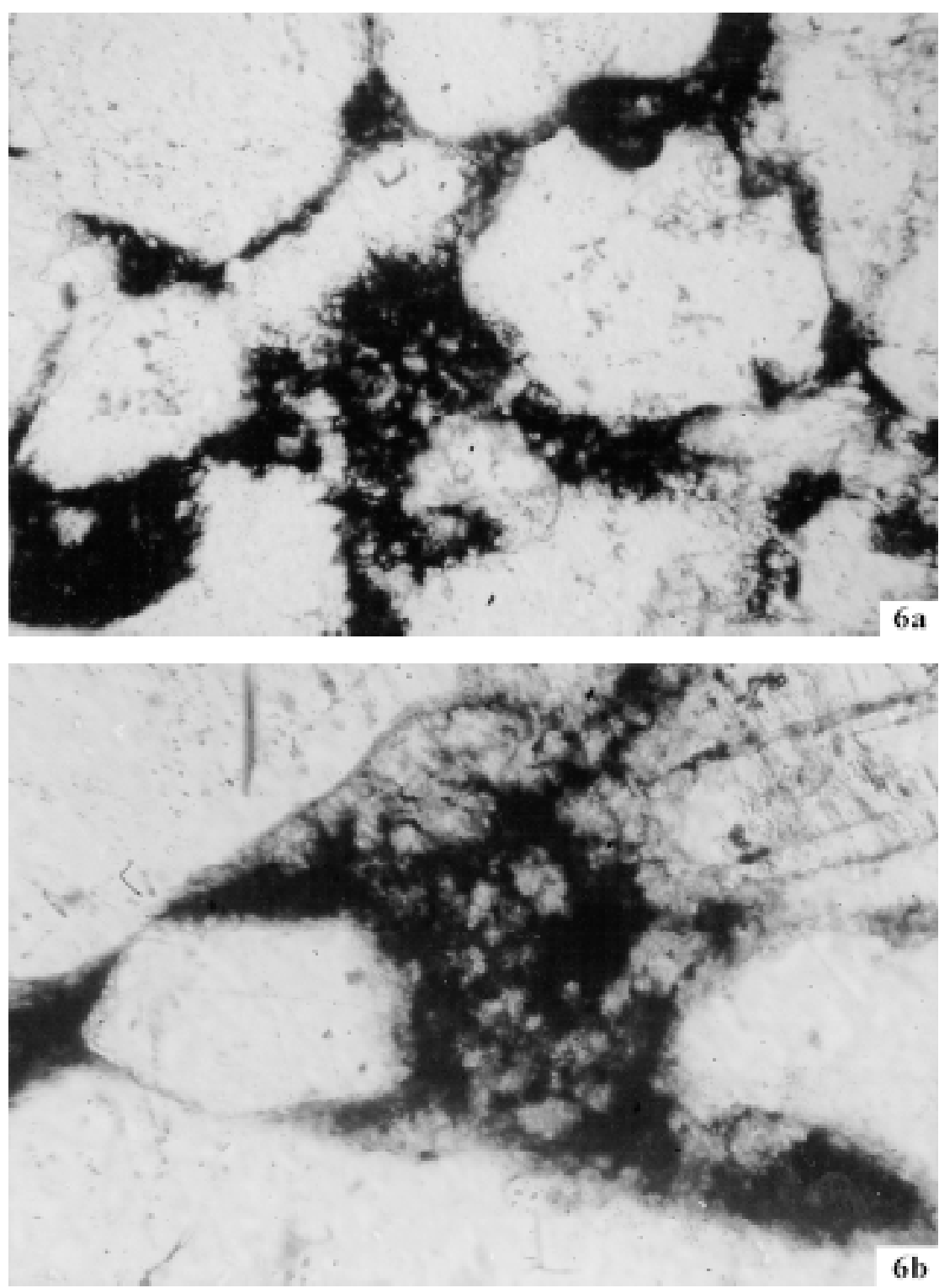

\section{Thin section observations}

Dark staining is present in many of the dark coloured samples, but also in smaller quantities in some of the grey to white samples. Identification of the dark staining as pyrobitumen in thin section is difficult for various reasons, and difficult to photograph for publications.

Pyrobitumen is opaque and therefore has no birefringence, but this alone can not distinguish pyrobitumen from amorphous iron oxides or grinding dust that also look opaque. Detection by microprobe is not possible because of the low atomic weight of carbon, although if nothing is detected, a substance with low atomic number must be present. Furthermore, the volume is so small that the amount of carbon is not significant in total carbon analysis. Consequently, pyrobitumen must be identified on properties that are not characteristic for other substances, and in that way exclude all other possibilities.

In a few samples, and particularly in one sample from Tvillinghuse, the staining is present as thin coatings only a few microns thick (Fig. 5a). The coatings have fractured into platelets less that 25 microns in diameter (Fig. 5b), with edges that are sometimes slightly upturned. The fracturing and upturning of edges show that the material is flexible and able to shrink, which is not a characteristic of crystalline substances. The only exception is smectitic clay minerals, but clay minerals have birefringence, and the observed material is opaque. 

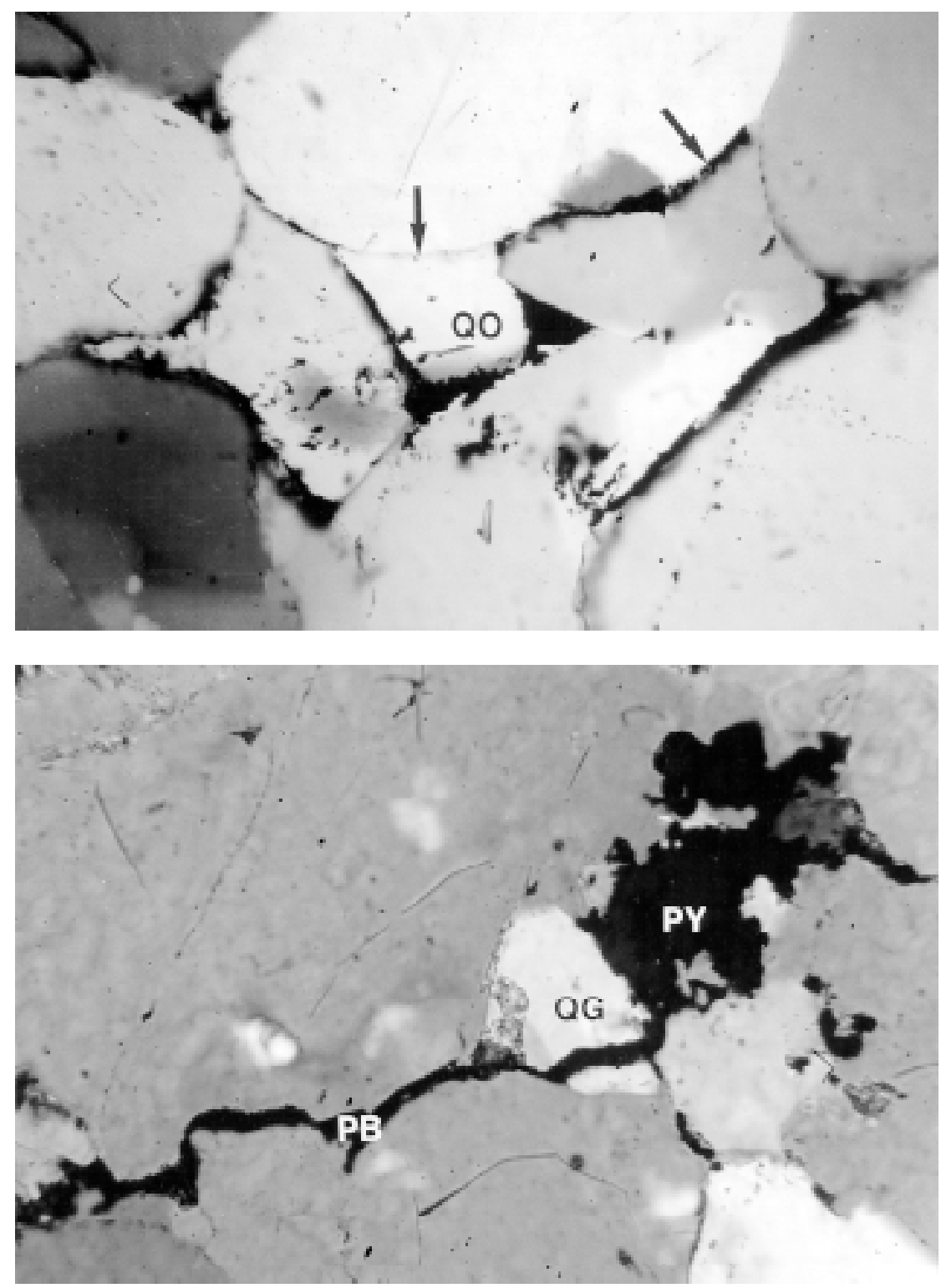

Figure 7. Large pore in Hardeberga Sandstone from Tvillinghuse with complex distribution of pyrobitumen and quartz cement.

Polarisers are crossed to show the origin of individual quartz overgrowths.

Pyrobitumen is present on both grain surfaces (right arrow) and on top of quartz overgrowths (QO). Most of the grains have pyrobitumen on surfaces beneath overgrowths, but in some cases there is no pyrobitumen on the grain surface (left arrow). Full width of image is $0.63 \mathrm{~mm}$.
Figure 8. Pyrobitumen (PB) and pyrite (PY) in fracture crosscutting both quartz cement and detrital quartz grains (QG). Crossed polarisers. Full width of image is $0.63 \mathrm{~mm}$.
The small amount of dark staining prevents accurate identification for all samples based on the above mentioned criteria. However, the identification as pyrobitumen is possible with some confidence in a few samples, suggesting that much of the dark material seen in other samples is also pyrobitumen.

Most of the dark pyrobitumen occupies the small pores in intergranular clay patches (Fig 6). The clay occur as isolated patches in over-size pores, or as an intergranular matrix-like material as shown in Figure 6 . All the remaining porespace is filled with quartz. The patchy clay must be of diagenetic origin, probably formed by replacement of detrital feldspar, but the matrix-like clay is probably also of diagenetic origin. The conclusion that the dark clay patches are anomalous is confirmed by the presence of other normally translucent clay patches that are not stained.

Although most of the dark pyrobitumen is situated directly on the surfaces of detrital quartz grains (Fig. 5 ), or in microporous clay, the pyrobitumen is sometimes found on both detrital grain surfaces and on quartz overgrowth crystal faces (Fig. 7). Also, a few examples were found where the pyrobitumen was present on the overgrowths, but not on the grain surface (Fig. 7). Although there are a few examples of pyrobitumen on top of quartz overgrowths, the vast majority of the dark pyrobitumen is situated directly on the surfaces of detrital grains or in clay patches.

In a few places pyrobitumen is present in fractures (Fig. 8). An example of this is the fracture shown in 


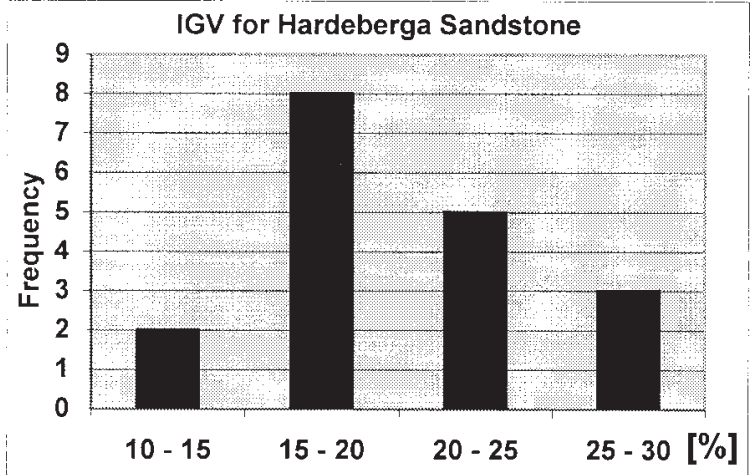

Figure 9. Frequency of intergranular volume (IGV) in Hardeberga Sandstone. Based on random pointcounts of 18 samples from various localities (Table 1).

Figure 8, which is filled with both pyrobitumen and pyrite, and crosscuts both quartz cement and detrital quartz grains. In all the studied sandstones, pyrite is found in close association with pyrobitumen.

The intergranular volume (IGV) is defined as the total percent volume of space between detrital grains, and is therefore the sum of the porosity and the cement. In the present study quartz cement and only minor amounts of clay, pyrobitumen, and other cements dominate the IGV. The IGV has been quantified through pointcounts, by distinguishing between detrital and intergranular volumes. A total of 18 thin sections of Hardeberga Sandstone were pointcounted (Table 1), and the frequency of IGV was plotted at $5 \%$ intervals (Fig. 9). Most samples have an IGV be- tween 15 and $20 \%$, with an average of $19.7 \%$, varying between $13.3 \%$ to $27.2 \%$.

\section{Discussion}

The intergranular clay is stained by pyrobitumen, and therefore the clay must have formed before the hydrocarbon migrated. Quartz is filling all remaining intergranular space between clay, pyrobitumen, and detrital grains and therefore the hydrocarbons must have migrated before quartz cementation. However, the few cases where pyrobitumen is situated on quartz overgrowths indicate that small amounts of quartz had already precipitated when the hydrocarbons migrated. Furthermore, pyrobitumen on both the detrital grain surface and on the quartz overgrowth suggests that there were two rather than one pulse of hydrocarbon migration. The fracture depicted in Figure 8 also indicates that some quartz precipitated before hydrocarbon migration. This fracture crosscuts a detrital quartz grain, which requires that the surrounding area was cemented by quartz before fracturing and hydrocarbon migration.

The close association of pyrite and pyrobitumen indicate that the pyrite formed when the hydrocarbons migrated. Pyrite is a common early diagenetic mineral but the pyrite in these sandstones formed after deep burial, sometimes post-dating quartz cementation. The sediment itself does not contain any source of sulphide for late pyrite formation, and the pyrite must therefore have formed in a reduced sulphide rich porefluid in association with the migrating hydrocarbons.
Figure 10. Preserved pore (P) with pyrobitumen coatings (long arrow), floating in a highly compacted area with extensive pressure solution (short arrows). Pore (P) is filled with quartz cement. Crossed polarisers. Full width of image is $0.63 \mathrm{~mm}$.

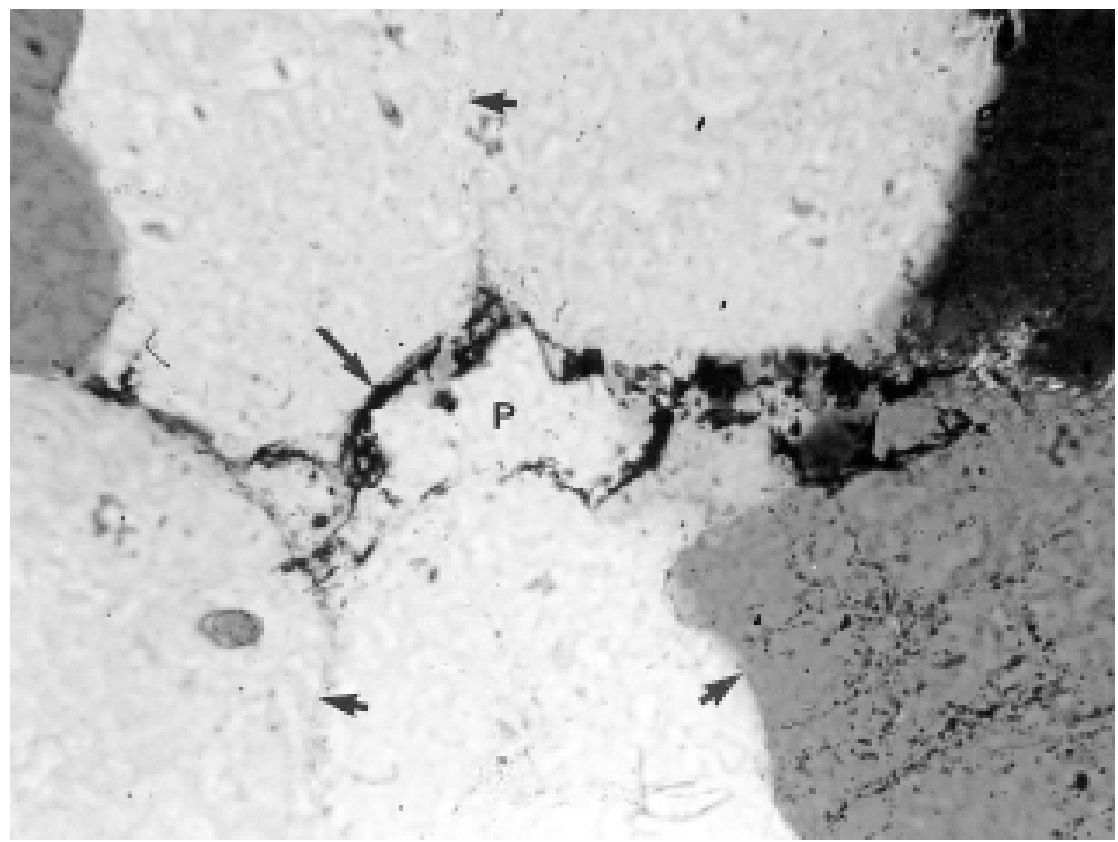


Table 1. Pointcount data for Hardeberga Sandstone. All numbers except numbers of points counted are in percent of present rock volume. 500 randomly chosen points were counted per thin section. except in one sample from Tvillinghuse where $600(2 \times 300)$ points were counted (see text). Present porosity included to illustrate the extent of cementation.

\begin{tabular}{|c|c|c|c|c|c|c|c|}
\hline Sample location & $\begin{array}{l}\text { Number of } \\
\text { points } \\
\text { counted in } \\
\text { thinsection }\end{array}$ & $\begin{array}{l}\text { Detrital } \\
\text { Volume }^{1} \\
\text { (Grains) } \\
\%\end{array}$ & $\begin{array}{l}\text { Quartz } \\
\text { cement } \\
\text { (IGV) } \\
\%\end{array}$ & $\begin{array}{l}\text { Other } \\
\text { cements } \\
\text { (IGV) } \\
\%\end{array}$ & Total & $\begin{array}{l}\text { Present } \\
\text { total IGV } \\
\%\end{array}$ & $\begin{array}{l}\text { Present } \\
\text { total } \\
\text { porosity } \\
\%\end{array}$ \\
\hline Strøby & 500 & 83.8 & 14.2 & 2.0 & 100.0 & 16.2 & 0.4 \\
\hline Strøby & 500 & 72.8 & 23.6 & 3.6 & 100.0 & 27.2 & 0.2 \\
\hline Pedersker & 500 & 74.6 & 21.0 & 4.4 & 100.0 & 25.4 & 0.0 \\
\hline Pedersker & 500 & 83.4 & 14.2 & 2.4 & 100.0 & 16.6 & 3.0 \\
\hline Àker & 500 & 83.2 & 7.4 & 9.4 & 100.0 & 16.8 & 0.6 \\
\hline Åker & 500 & 86.0 & 5.0 & 9.0 & 100.0 & 14.0 & 0.8 \\
\hline Åker & 500 & 75.6 & 21.8 & 2.6 & 100.0 & 24.4 & 1.8 \\
\hline Snogebæk & 500 & 78.6 & 14.0 & 7.4 & 100.0 & 21.4 & 0.0 \\
\hline Snogebæk & 500 & 79.8 & 20.2 & 0.0 & 100.0 & 20.2 & 0.2 \\
\hline Kastelsbakken & 500 & 82.2 & 16.8 & 1.0 & 100.0 & 17.8 & 0.8 \\
\hline Kastelsbakken & 500 & 78.2 & 19.6 & 2.2 & 100.0 & 21.8 & 1.0 \\
\hline Balka strand & 500 & 82.6 & 14.2 & 3.2 & 100.0 & 17.4 & 2.0 \\
\hline Hundshale & 500 & 83.0 & 7.4 & 9.6 & 100.0 & 17.0 & 2.4 \\
\hline Godthaab & 500 & 74.4 & 21.6 & 4.0 & 100.0 & 25.6 & 3.2 \\
\hline Godthaab & 500 & 79.2 & 17.0 & 3.8 & 100.0 & 20.8 & 3.6 \\
\hline St. Hallegaard & 500 & 81.0 & 15.4 & 3.6 & 100.0 & 19.0 & 0.6 \\
\hline Tvillinghuse* & 300 & 81.0 & 18.0 & 1.0 & 100.0 & 19.0 & 0.0 \\
\hline Tvillinghuse ${ }^{* *}$ & 300 & 86.7 & 6.3 & 7.0 & 100.0 & 13.3 & 2.0 \\
\hline Average & & 80.3 & 15.4 & 4.2 & 100.0 & $19.7(+/-3.9)$ & 1.3 \\
\hline
\end{tabular}

${ }^{1}$ Volume of detrital grains. Usually more than $90 \%$ quartz, some feldspar and few accessory grains like mica and opaque minerals. The volume includes replaced detrital grains and intragranular porosity.

${ }^{2}$ Illitic clay (diagenetic), anatase, pyrobitumen, pyrite, detrital matrix, etc. Includes intergranular porosity.

${ }^{3}$ Present total porosity may be intragranular or intergranular and is therefore included in "Detrital volume" and "Other cements" respectively to get the right ratio of detrital and intergranular volume.

*Area with pyrobitumen coatings

${ }^{* * *}$ Compacted area with no pyrobitumen coatings

From the observations and discussion above it is clear that the Hardeberga Sandstone was not completely cemented when the Alum Shale generated oil. On the contrary the sandstones had considerable porosity. Sandstones do not decompact when uplifted, and because hydrocarbons migrated through the Hardeberga Sandstone before significant quartz cementation, the porosity must have been at least as high as the present intergranular volume of $19.7 \%$.

IGV of a newly deposited well-sorted sandstone similar to the Hardeberga Sandstone is of the order of 45\% (Atkins \& McBride 1992). Given that IGV at maximum mechanical compaction is in the order of 25-30\%, pressure solution must have contributed 5$10 \%$ of the compaction of Hardeberga Sandstone. This implies that the Hardeberga Sandstone is extensively compacted, but because quartz cement retards mechanical compaction, most of the compaction must have happened before quartz cementation.

It has been mentioned that the average IGV of the examined thin sections is $19.7 \%$, but a few samples have IGVs much lower than this value. This poses the question as to whether these samples had this low IGV when the hydrocarbons migrated, or did the compaction continue after hydrocarbon migration. One particular sample was selected in order to answer this question, since approximately one half of the thin section has relatively high IGV, and the other half a very low IGV. The sample half with high IGV also has easily identifiable pyrobitumen coatings. Each half of the thin section was pointcounted, but because of the limited area, only 300 points were counted in each half.

The count from the area with easily identifiable pyrobitumen coatings (Fig. 5) has an IGV of 19\%, whereas the adjacent area with no coatings has an IGV of only $13.3 \%$ (Table 1 ). The area containing pyrobitumen has an IGV close to the average value for the sandstone, whereas the more compacted half is showing extensive pressure solution contacts and strained quartz grains. However, in the part of the thin section that is clearly much more compacted, there are isolated pores with pyrobitumen coatings, not showing any sign of further compaction (Fig. 10). These pores with adjacent grains can be visualised as small "islands" or remnant areas of the texture seen in the other half of the thin section with preserved 
Figure 11. Cathodoluminescens image of highly compacted Hardeberga Sandstone from Pedersker Quarry. This particular area has an IGV of only $9 \%$. Full width of image is $0,85 \mathrm{~mm}$. $\mathrm{QG}=$ quartz grain.

$\mathrm{QC}=$ quartz cement. $\mathrm{PS}=$ pressure solution.

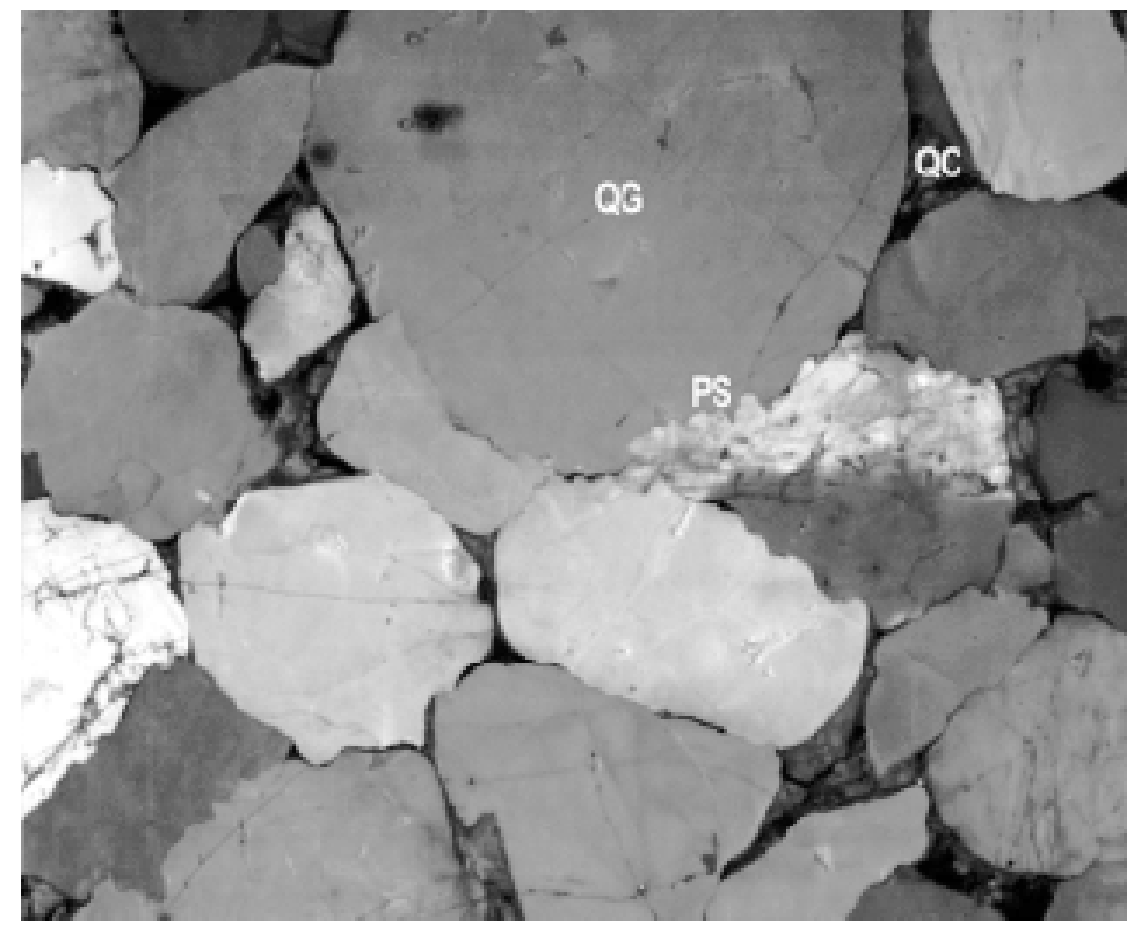

pyrobitumen coatings (Fig 5). These observations indicate that a larger part of the sandstone had a texture originally similar to the one described above with pyrobitumen coatings, but was subsequently destroyed by further compaction and pressure solution.

The more compacted section is not anomalously dark in colour, and this raises the question as to whether the oil was ever deposited on the grain surfaces, or was subsequently removed during continued compaction. Early quartz cement in compacted areas without pyrobitumen could have prevented oil migration but in this case it should be less compacted than the surroundings, and this is not the case. An example of strongly compacted Hardeberga Sandstone from Pedersker Sandstone Quarry with extensive compaction and pressure solution is shown in Figure 11. This particular area has an IGV of only $9 \%$ that is even lower than the value obtained above for the Tvillinghuse sample. This degree of compaction would not have been possible if there had been extensive earlier quartz cementation.

However, samples with high IGV do not always show clear evidence of hydrocarbon migration, and therefore the lack of pyrobitumen can not always be explained by further compaction. Areas with high IGV can have been cemented by quartz before hydrocarbon migration, but this requires that quartz formed early in some areas and much later in other areas, which is not the nature of quartz. Another explanation is that the hydrocarbons filled only part of some beds, or sometimes did not leave any trace.
This study has shown that the sandstones were not cemented until after the hydrocarbon generation and that the quartz cement did not precipitate until very deep burial. When compaction, expressed as IGV, is plotted versus an arbitrary time scale, quartz cementation and hydrocarbon migration can be indicated at the known minimum IGV (Fig. 12). The Hardeberga Sandstone had an IGV of at least $19.7 \%$ when hydrocarbons migrated and quartz cementation commenced simultaneously or just before hydrocarbon migration. Although some samples of the Hardeberga Sandstone show signs of continued compaction, quartz cementation probably slowed further compaction shortly

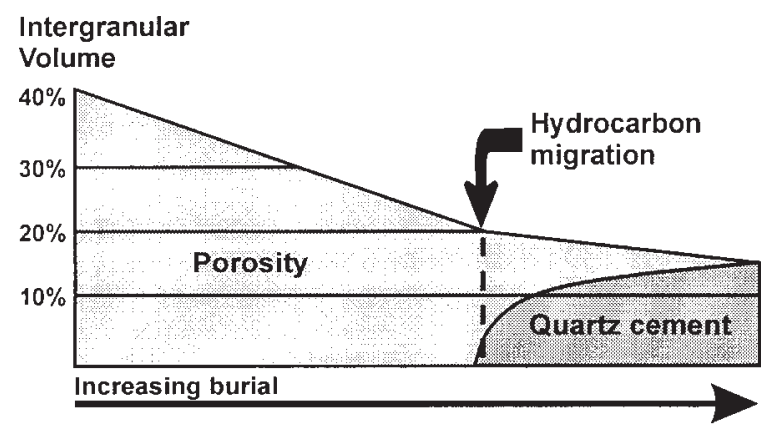

Figure 12. Summary. Timing of hydrocarbon migration and quartz cementation relative to compaction expressed as IGV. IGV is plotted versus burial on an arbitrary scale representing increased burial. See text for explanation. 
after hydrocarbon migration, and ultimately stopped compaction at about $20 \%$ IGV.

Unfortunately the depth of quartz cementation cannot be determined accurately from compaction studies and petrography alone. However, in comparison with other compaction studies, an IGV of about $20 \%$ could indicate burial in excess of $5000 \mathrm{~m}$ (Wilson \& McBride 1989), whereas other studies estimate much lower depths (Baldwin \& Butler 1985), or considerable scatter (Bloch 1991). Compaction of different sandstones at similar depth depends on various factors, but particularly the amount of ductile grains (Pittman \& Larese 1991). The Hardeberga Sandstone contains no ductile grains and is therefore able to withstand considerable stress. This makes compaction slower and the burial depth may be underestimated.

The only possible source rock for hydrocarbons during the Mid Palaeozoic subsidence is the Cambrian to Ordovician Alum Shale (Buchardt et al. 1997). However, this formation is stratigraphically above the Lower Cambrian sandstones (Fig. 1), and because hydrocarbons are lighter than water and all feasible porefluid compositions, block faulting probably brought the Alum Shale to a lower position enabling the generated hydrocarbons to enter the sandstones. If IGV was indeed as high as postulated and no other cements were clogging the pores, both porosity and permeability was high, and long distance migration was possible. The hydrocarbons can have entered the sandstones many kilometres laterally from where they are now found in the sandstones, and possibly outside the present onshore area of Bornholm.

Quartz cementation is related to depth of burial, and the Hardeberga Sandstone may therefore be porous in other locations where it has not been buried so deep. Maps of thermal maturity of the Scandinavian area (Buchardt et al. 1997) show that thermal maturity, and consequently maximum depth of burial decreases north and northeast of the onshore Bornholm area. Active oil and gas-fields are located in the Baltic Sea east and northeast of Bornholm in sediments with vitrinite-like reflectance values between $0.55 \%$ and $1.40 \%$ (Buchardt et al.1997) whereas vitrinite-like reflectance values onshore Bornholm are as high as 2.5\% (Buchardt \& Lewan 1990). If sandstones are present here they have not been buried as deep as the onshore Bornholm area, and therefore may not be cemented by quartz.

\section{Conclusion}

It has previously been assumed that the Lower Cambrian sandstones were already cemented when the Alum Shale generated oil (Buchardt et al. 1997). However, the present study has shown the contrary that even though compaction was extensive before oil migration and quartz cementation, the sandstones had excellent reservoir properties with a porosity of at least $19.7 \%$ and probably also a high permeability at the time of oil generation.

\section{Dansk Sammendrag}

Den nedre kambriske Hardeberga Sandsten (Balka Sandsten) er kendt som en hvid eller grå sandsten, men på mange lokaliteter på Bornholm er sandstenen meget mørk eller helt sort. På tilsvarende vis er de ligeledes nedre kambriske Rispebjerg Sandsten og Nexø Sandsten også lokalt sortfarvede. Der har været en del spekulationer angående årsagen til sortfarvningen, men en præcis identifikation mangler. Kaj Hansen kaldte i 1936 de mørke arkoser sydøst for Aakirkeby for blågrå arkoser, og opfattede dem som en særskilt lithologi. Denne artikel påviser at sortfarvningen stammer fra pyrobitumen, som er et restprodukt efter hydrokarboner, der migrerede gennem sandstenene i forbindelse med den Kaledoniske Orogenese i midten af Palæozoikum. Arbejdet er fortrinsvis foretaget på Hardeberga Sandsten, men de fleste observationer gælder også for Nexø Sandsten og Rispebjerg Sandsten.

Tidligere bassinanalytiske studier og studier af stabile isotoper og væskeindeslutninger har påvist, at det bornholmske område blev dybt begravet midt i Palæozoikum. Alun Skiferen må derfor have genereret olie, men opfattelsen har hidtil været, at de nedre kambriske sandsten allerede var cementeret før oliedannelsen, og derfor ikke kunne indeholde olie.

I tyndslib ses, at sandstenene indeholder pyrobitumen som belægninger på korn eller i mikroporøst ler. Da pyrobitumenen ligger på overfladen af kornene, må kvartscementen været dannet efter at hydrokarbonerne migrerede gennem sandstenen. Det kan ydermere konkluderes, at da sandsten ikke dekompakterer ved hævning, må det nuværende intergranulære volumen (IGV) have været porøsitet, da hydrokarbonerne var tilstede.

Ved punkttællinger er det nuværende IGV bestemt til gennemsnitlig 19,7\%. En nyaflejret sandsten har typisk en IGV på omkring 45\%, og maksimal mekanisk kompaktion nås omkring 25-30\% IGV. Hardeberga Sandstenens IGV på 19,7\% viser derfor, at den er stærkt mekanisk og kemisk kompakteret ved trykopløsning. Udbredt cement vil stoppe kompaktion, og sandstenen må derfor have været dybt begravet før kvartscementering. Dette indikerer at de samme sandsten i andre områder, som ikke har været ude for den samme begravelsesdybde, måske stadig besidder de gode reservoiregenskaber, som de bornholmske sandsten havde da Alun Skiferen genererede olie. 


\section{References}

Atkins, J. E. \& McBride, E. F. 1992: Porosity and packing of Holocene river, dune, and beach sands. American Association of Petroleum Geologists Bulletin 76, 339-355.

Baldwin, B. \& Butler, C. O. 1985: Compaction curves. American Association of Petroleum Geologists Bulletin 69, 622-626.

Bloch, S. 1991: Empirical prediction of porosity and permeability in sandstones. American Association of Petroleum Geologists Bulletin 75, 1145-1160.

Buchardt, B. \& Lewan, M. D. 1990: Reflectance of vitrinite like macerals as a thermal maturity index for CambroOrdovician Alum Shale, Southern Scandinavia. American Association of Petroleum Geologists Bulletin 74, 394-406.

Buchardt, B. \& Nielsen, A. T. 1985: Carbon and oxygen isotope composition of Cambro-Silurian limestone and anthraconite from Bornholm: Evidence for deep burial diagenesis. Bulletin of the Geological Society of Denmark 33, 415-435.

Buchardt, B., Nielsen, A. T. \& Schovsbo, N. H. 1997: Alun skiferen i Skandinavien. Geologisk Tidsskrift 1997, 3, 33 pp.

Clemmensen, L. B. \& Dam, G. 1993: Aeolian sand-sheet deposits in the Lower Cambrian Neks $\varnothing$ Sandstone Formation, Bornholm, Denmark: architecture and genesis. Sedimentary Geology 83, 71-85.

Folk, R. L. 1980: Petrology of sedimentary rocks. Hempill, Austin, Texas, 184 pp.

Gry, H. 1936: Om Nexø sandstenen og "Aakerformationen” en tungmineral korrelation. Bulletin of the Geological Society of Denmark 9, 27-42.

Grönwall, K. A. \& Milthers, V. 1916: Beskrivelse til geologisk kort over Danmark. Kortbladet Bornholm. Danmarks Geologiske Unders $\varnothing$ gelse, I række, 13, 281 pp.

Hamberg, L. 1991: Tidal and seasonal cycles in a Lower Cambrian shallow marine sandstone (Hardeberga Fm.) Scania, Southern Sweden. In Smith, D. G., Reinson, G. E., Zaitlin, B. A. \& Rahmani, R. A. (eds.) Tidal Sedimentology. Canadian Petroleum Geology Memoir 16, 255-274.

Hansen, K. 1936: Die Gesteine des Unterkambriums von Bornholm. Danmarks Geologiske Undersøgelse, II række, 62, 194 pp.

Hansen, K. 1937: Sammenlignende studier over Kambriet i Skåne og på Bornholm i nedre Kambrium. Bulletin of the Geological Society of Denmark 9, 151-183.

Jensen, S. K. \& Nielsen, S. B. 1995. Estimating amount and timing of Late Paleozoic uplift and erosion in the Rønne Graben, Bornholm, Denmark. Bulletin of the Geological Society of Denmark 42, 23-33.

Jensenius, J. 1987: Regional studies of fluid inclusions in Palaeozoic sediments from southern Scandinavia. Bulletin of the Geological Society of Denmark 36, 221-235.

Pittman, E. D. \& Larese, R. E. 1991: Compaction of lithic sands: experimental results and applications. American Association of Petroleum Geologists Bulletin 75, 12791299.

Thomsen, E., Lindgreen, H. \& Wrang, P. 1983: Investigation on the source rock potential of Denmark. Geologie Mijnbouw 62, 221-239.

Vejbæk, O. V., Stouge, S. \& Poulsen, K. D. 1994: Palaeozoic tectonic and sedimentary evolution and hydrocarbon prospectivity in the Bornholm area. Danmarks Geologiske Undersøgelse, Serie A, 34, 31 pp.

Wilson, J. C. \& McBride, E. F. 1988: Compaction and porosity evolution of Pliocene sandstones, Ventura Basin, California. American Association of Petroleum Geologists Bulletin 72, 664-681. 